\title{
SPECIFICITY OF REMUNERATION FOR PUBLIC SERVANTS
}

\author{
Oleksii Drozd', Viktor Kostiuk², Vasyl Ilkov³
}

\begin{abstract}
The aim of the article is to determine the specificities of the remuneration for public servants in Ukraine. The subject of the study is the remuneration for public servants in Ukraine. Methodology. The study is based on the use of general scientific and special-scientific methods and techniques of scientific knowledge. The dialectical method enabled to interrogate the development of the institution of remuneration for public servants in Ukraine. The comparative legal method enabled to compare doctrinal approaches to this issue. The system-structural method enabled to determine the elements of the remuneration for public servants. Methods of analysis and synthesis helped study separate parts of this institute to formulate further conclusions about its most optimal functioning. The logic-semantic method was used to determine the content of the concept of "remuneration for public servants". The normative-dogmatic method enabled to analyse the content of legal regulations of the domestic legislation on the issue. Practical implications. The determination of the specificities of the remuneration for public servants in Ukraine enabled to make recommendations for improving the remuneration system of this category of workers, as well as identify problematic issues that require further consideration and research. Relevance/originality. The author's definition of the concept of "remuneration for public servants" is proposed and the specific features of this institute, insufficiently studied before, are analysed. The article analyses the specificities of the remuneration for public servants. Their list is determined and the content of each of them is disclosed. The specificities of the remuneration for public servants are substantiated in comparison with other categories of employees.
\end{abstract}

Key words: remuneration, public servants, public service, labour, working conditions.

JEL Classification: M54, F66, J08

\section{Introduction}

The performance of a workforce depends on many factors, such as organizational (for example, the level of organization of labour in an enterprise, institution or organization), socio-economic (working conditions, material and social security), material and technical (the novelty of the technologies used in the work process), etc. Along with the listed elements, primarily, ensuring the performance depends on the perfection of the system of remuneration, because remuneration is the main motivation of a person to work. In this context, public servants are no exception.

Public servants are a special category of employees because the effectiveness of the adoption of state management decisions and the state bodies' responsibility and function execution depends directly on their official activity. For such persons to implement their official competence in a proper manner, material incentives for good and high-quality work are necessary. The system of remuneration for public servants, in contrast to other categories of citizens, is regulated by the rules of a special legal act, the Law of Ukraine
"On Public Service" No. 889-VIII as of December 10, 2015 (Pro derzhavnu sluzhbu, 2016), as well as decrees of the President of Ukraine, resolutions of the Cabinet of Ministers of Ukraine, etc. The specific nature of the remuneration for public servants, in addition to the specificities of the labour functions of such persons, is also predetermined by the need to increase the motivation of public servants and the interest of highly qualified specialists in entering the public service.

The relevance of the study of the specifics of the remuneration for public servants is also predetermined by the fact that the public service is the corruptionrelated sphere. Corruption is one of the most threating phenomena of the present day, which negatively affects public administration and reduces the efficiency of state authorities and local self-government. One of the main incentives for the development of public service personnel, as well as refraining from corruption, is the remuneration of labour at the appropriate rate enough to satisfy most needs of public servants. Therefore, the issue of the specificity of the remuneration for public servants remains relevant for research.

\footnotetext{
Corresponding author:

${ }^{1}$ National Academy of Internal Affairs, Ukraine.

E-mail: alex0674682444@gmail.com

${ }^{2}$ National University of Ostroh Academy, Ukraine.

${ }^{3}$ Dnipropetrovsk District Administrative Court, Ukraine.
} 


\section{Literature review}

In the scientific literature, many works are devoted to this issue. However, considering the recent adoption of the Law of Ukraine "On Public Service" as of December 10, 2015 (Pro derzhavnu sluzhbu, 2016), as well as the fact that mostly, the remuneration for public servants is considered in certain aspects (for example, as a prevention of corruption as motivation, as an encouragement, or according to its constituents), the specificity of the remuneration for public servants have not been properly investigated nowadays. Thistheoreticalinstituteisformed duetothe contribution of the experts of the legal and economic sciences, such as M. O. Bahmet, V. D. Bondar, V. M. Vehera, A. O. Holovachova, M. S. Ivanov, M. I. Inshyn, M. R. Kapinus, O. V. Kuzmenko, I. H. Pakhonova, O. A. Sokolova, V. B. Tyshchenko, V. S. Furtatov, V. M. Shchehortsov, and others. However, given the recent reform of the legislation on public service, an analysis of the current specificity of the remuneration for public servants is topical.

\section{Main material}

In their works, domestic scholars prefer to consider the remuneration as rewards, which the owner or an authorized body pays to an employee for the work performed, and which is simultaneously a means to motivate the worker to improve the performance and a way to meet his/her needs (Holovachova, 2016). Such a definition reveals that nowadays labour remuneration is a major incentive for workers to improve performance, as well as for professional development. In addition, the remuneration enables a person to maintain his/ her standard of living that satisfy basic needs or higher. Therefore, in the context of the institution under consideration, analysis of this definition leads to the conclusion that the state remuneration system of public servants is a guarantee of the effective public service because in this way public servants are motivated to realize their own potential while performing their professional duties.

In economic science, remuneration is considered as a complex multidimensional economic phenomenon, which reflects the interaction of many economic processes, as an important element of social reproduction and development of the market relations system, as well as a category, designed to ensure a decent standard of living (Dorohan-Pysarenko, 2014). In this study, the abovementioned concept is not suitable, because it contains a vaguely worded essence of the category under the study, such as "interaction of many economic processes." Therefore, the nature of remuneration remains unclear, as well as its preconditions or application. Therefore, in our opinion, the interpretation of the essence and specificity of the remuneration for public servants due to such a definition is not appropriate.
Formulating the definition of the "remuneration for public servants," the role of such persons in the functioning of state institutions should be considered, the state is obliged to provide a decent remuneration, both at the entry into office and throughout the official career. V. M. Vehera argues that the rate of the pay depends on socio-economic capacities of the state, but such payments must ensure the constitutional right of everyone to an adequate standard of living for themselves and their families. The state creates for a person the conditions, under which he/she has the opportunity by the work to really provide vital functions for themselves and their families (Vehera, 2015). Therefore, in its essence, the remuneration for public servants must meet the following conditions: 1) the state must create all conditions for a person to exercise his/her right to work in the public service; 2) the total remuneration for public servants depends on the socio-economic capabilities of the state; 3 ) the state is obliged to ensure a decent remuneration for public servants, both at the time of entry into office and throughout the official career; 4) the rate of the remuneration for public servants should correspond to the specificity of their official competence and the importance of the functions performed; 5) the total remuneration for public servants must ensure the livings of the public servant and his family members.

M. R. Kapinus distinguishes the following specificities of the remuneration for public servants contrasting to other types of remuneration: 1) the salary of public servants must ensure an adequate standard of living for an employee and his family; 2) the salary of public servants should ensure attraction and retaining competent and highly-skilled staffs; 3 ) the salary of public servants should ensure the avoidance of corruption and increase the efficiency of the public service functioning (Kapinus, 2005). Each of these features is appropriate. First, as repeatedly noted, the main purpose of remuneration for any person is to ensure livings for him/her and members of his/her family. Second, its rate must be competitive in the labour market because the public service needs qualified personnel. In addition, the attraction of high-quality personnel does not guarantee that such an employee will remain in service for a long period. Third, the rate of the salary of a public servant should be sufficient to avoid corruption risks.

The analysis of the provisions of the Law of Ukraine "On Public Service" No. 889-VIII as of December 10, 2015 (Pro derzhavnu sluzhbu, 2016) confirms the absence of the definition of "remuneration for public servants" in it. However, the analysis of the content of this legal act reveals that part 1 of Article 50 states that the state provides an adequate remuneration for public servants for the professional performance of official duties, encourages them to perform in productive, effective, faithful and initiative manner. Therefore, considering only specificity of the sphere, the following 
essential features of the remuneration for public servants can be distinguished: 1) the level of the pay should be adequate for the professional performance of official duties; 2) the remuneration for public servants should encourage them to work in a productive, effective, faithful and initiative manner.

Therefore, the remuneration for public servants is a remuneration, paid in conditions created by the state in accordance with its socio-economic capabilities, which is decent both at the time of entry into office and throughout the official career for the professional performance of official duties, corresponding to the specificity of the official competence and the importance of the functions performed by a public servant, designed to provide livelihoods of the public servant and his/ her family members, as well as the remuneration for public servants should encourage him/her to work in a productive, effective, faithful, and initiative manner and to avoid corruption.

The review of the scientific literature reveals that the specificity criteria for the remuneration for public servants are not considered by domestic scientists. In A. A. Sokolova's work, the specificity of the remuneration for public servants is conveyed, according to the following criteria: 1 ) the subject of receiving, that is, a public servant; 2) the subject of implementation, that is, the state represented by its body; 3 ) the source of funds, that is, the state budget; 4) implemented in the order, at the rate and on the terms established by the legislation; 5) provided for the official activities of public servants; 6) made in the form of regular monetary payments (Sokolova, 2016). In our opinion, most of these categories certify the specificity of the remuneration for public servants, however, according to the regulations of the Law of Ukraine "On Public Service" No. 889-VIII as of December 10, 2015 (Pro derzhavnu sluzhbu, 2016), in the remuneration for public servants, a number of really specific features remain unaddressed. Firstly, according to part 2 of Article 50 of the Law, remuneration has a special structure, which is a salary, various allowances, recompenses and premiums. Secondly, Article 51 of the Law provides for remuneration groups and a public servant salary scheme, which is also worthwhile disclosing as a specific feature of the remuneration for public servants. Some of the features listed are inappropriate. For example, the feature "provided for the official activities of public servants" does not disclose the specificity of the remuneration for public servants, since the remuneration of all categories of workers is provided for labour (official) activities. The feature "made in the form of regular monetary payments" is also not suitable for the following reasons. Firstly, Article 94 of the Labour Code of Ukraine (Kodeks zakoniv pro pratsiu Ukrainy) provides for that a salary is a remuneration, calculated in monetary terms as a rule. That is, the form of monetary payment is not a solely specific feature for the remuneration for public servants but extends to almost all types of employment relationships. Secondly, in this context, it is more appropriate to distinguish the structure of the remuneration for public servants as a specific feature.

Therefore, the specificity of the remuneration for public servants is:

1) the subject of receiving remuneration is a public servant;

2) the subject of implementation of remuneration is the state represented by its body;

3) the source of funds is the State Budget of Ukraine;

4) in a special structure, containing the salary, various allowances, recompenses and bonuses;

5 ) in special remuneration groups and salary schemes of public servants.

1. The subject of receiving remuneration is a public servant. According to part 2 of Article 1 of the Law of Ukraine "On Public Service" No. 889-VIII as of December 10, 2015 (Pro derzhavnu sluzhbu, 2016), a public servant is a citizen of Ukraine who holds public service position in a state authority, another state body, its staff (secretariat), receives salaries at the expense of the state budget and implements official powers established for this position, and directly related to the execution of the responsibilities and functions of this public body, and also adheres to the principles of public service. It should be noted that even the legislative definition emphasizes that public servants receive a salary for the performance of official duties. Such persons are citizens who work in state authorities and local self-government and play an important role in solving the tasks of the Ukrainian state. Ensuring the fulfilment of these tasks also depends on the remuneration for public servants. Consequently, the specificity of this feature is that remuneration can be made only in relation to one group of citizens, clearly defined in the Law, that is, public servants.

2. The subject of implementation of remuneration is the state represented by its body. In part 2 of Article 5 of the Law of Ukraine "On Remuneration" No. 108/95-VR as of March 24, 1995 (Pro oplatu pratsi), the subjects of remuneration organization include state authorities and local self-government bodies. In this context, "remuneration organization" means that total remuneration for public servants is determined at the state level. A specific public authority or local government, in which a public servant works, does not accumulate salary funds and does not affect its employees' salaries by its decisions. The state body is obliged to remunerate an employee but carries out only its organizational part. The specificity of this feature is that the subject of implementation of the remuneration for public servants is actually two-levelled: at the first level, the state that forms the salary fund of public servants and determines the amount of the remuneration for public servants; at the second level, state authorities and local self-government bodies are responsible for paying such funds. 
3. The source of funds is the State Budget of Ukraine. This is evidenced, first, by the analysis of part 2 of Article 1 of the Law of Ukraine "On Public Service" No. 889-VIII as of December 10, 2015 (Pro derzhavnu sluzhbu 2016), which states that a public servant receives salaries at the expense of the state budget. Second, Part 4 of Article 150 of the Law of Ukraine "On Public Service" No. 889-VIII as of December 10, 2015 (Pro derzhavnu sluzhbu 2016) stipulates that the source of the payment fund for the remuneration for public servants is the state budget. Namely, the remuneration fund for public servants is formed at the expense of the state budget, as well as funds from the state budget within the framework of assistance programs of the European Union, foreign governments, international organizations, donor institutions. Therefore, the procedure for the use of such funds coming to the state budget shall be approved by the Cabinet of Ministers of Ukraine, and not directly by state authorities and local self-government bodies. Furthermore, the regulation of Article 4 of the Law of Ukraine "On Remuneration" No. 108/95-VR as of March 24, 1995 (Pro oplatu pratsi) provides for that for institutions and organizations financed from the budget (i.e., state bodies), the source of funds for remuneration are funds allocated from the corresponding budgets, grants. Thus, since the state authorities and local self-government are non-profitable, the indicated feature is that their full maintenance, including personnel remuneration, is carried out at the expense of the state.

4. A special structure, containing the salary, various allowances, recompenses, and bonuses. Part 2 of Article 150 of the Law of Ukraine "On Public Service" No. 889-VIII as of December 10, 2015 (Pro derzhavnu sluzhbu 2016) stipulates that public servant remuneration shall form the following components: 1) salary; 2) allowances for seniority; 3) public service allowance; 4) recompense for an additional workload due to the performance of duties of a temporarily absent public servant in the amount of 50 percent of the official salary of a temporarily absent public servant; 5) recompense for additional workload in connection with the performance of vacant position duties of public service at the expense of saving the salary fund for the corresponding position; 6) bonuses (in case of assigning). An analysis of Article 52 of this legal regulation demonstrates that the allowances may be established for each calendar year of public service experience or for rank, and recompense may be established for an additional workload due to the performance of duties of a temporarily absent public servant or for the vacant position of public service. In turn, the main criterion for a bonus is the personal contribution of a public servant to the overall performance of the state body, or a bonus may be paid monthly, quarterly or annually in accordance with the decision of the head of the public service.
The specificity of this feature is in the specified structure of remuneration inherent exclusively in the public service.

5. Special remuneration groups and salary schemes of public servants. The last specific feature of the remuneration for public servants is linked to special remuneration groups and public servants salary schemes. Part 1 of Article 51 of the Law of Ukraine "On Public Service" No. 889-VIII as of December 10, 2015 (Pro derzhavnu sluzhbu 2016) provides for that public service positions are divided into nine groups: 1) heads of state bodies; 2) first deputies of heads of state bodies; 3 ) deputy heads of state bodies; 4) heads of independent structural units of state bodies; 5) deputy heads of independent structural units of state bodies; 6) heads of departments of independent structural units of state bodies and their deputies; 7) chief specialists of state bodies; 8) leading specialists of state bodies; 9) specialists of state bodies. In fixing the salary for each group of public servants, their jurisdiction over the state or local government body is considered, for example, whether it applies to the entire territory of Ukraine or to the territory of one or more regions, or to the territory of one or several regions, cities of regional significance. Consideration of the groups of public servants and the jurisdictions of the state bodies in which they are serving enables to set up the amount of their remuneration. For example, part 3 of Article 51 of the Law of Ukraine "On Public Service" No. 889-VIII as of December 10, 2015 (Pro derzhavnu sluzhbu 2016) provides for that the minimum salary of the first group in state bodies, which jurisdiction extends over the entire territory of Ukraine, is not more than seven minimum salaries of the ninth group of state bodies, which jurisdiction extends to the territory of one or several regions and cities of regional significance. This enables to conclude: first, the public servants of the first group claim, above all, the maximum possible remuneration; second, public servants of bodies which jurisdiction extends over the entire territory of Ukraine also have advantages in remunerating employees of other government agencies. The lowest level on this list is the employees of state and local self-government bodies, which jurisdiction is valid on the territory of one or several regions or cities of regional significance. In addition, the total remuneration for public servants may not be less than two minimum subsistence incomes for ablebodied persons, the rate of which is set for January 1 of the calendar year, and which is 1762 hryvnias as of January 1, 2018. Therefore, the specificity of the remuneration for public servants is specifics of its rate fixing, since it takes into account the following criteria: 1) the particularity of the public service position; 2) the jurisdiction of the body in which he/she works; 3) the minimum subsistence income for able-bodied persons as of January 1. 


\section{Conclusions}

Therefore, the remuneration for public servants significantly differs from the remuneration of any other categories of employees. Above all, the provisions of a special legal act regulate it, with no less importance of decrees of the President of Ukraine and resolutions of the Cabinet of Ministers of Ukraine, etc. The subjects of receiving such payments are only persons who occupy a position in the public service in a state body or local government. Meanwhile, the state body carries out exclusively an organizational role, and the state carries out the formation of salary funds, as well as fixes the amount of remuneration. In addition, salaries of public servants are characterized by a special structure and payroll. This is determined by the specificity of the labour function of a public servant to fulfil the responsibilities of the state.

\section{References:}

Pro derzhavnu sluzhbu (2016). [On Public Service]. Vidomosti Verkhovnoi Rady Ukrainy, 4, 43. (in Ukrainian)

Holovachova, A. O. (2016). Materialna skladova motyvatsiinoho mekhanizmu efektyvnoi pratsi derzhavnykh sluzhbovtsiv [The material component of the motivational mechanism for efficient work of public servants]. Zbirnyk naukovykh prats Kharkivskoho natsionalnoho pedahohichnoho universytetu imeni H. S. Skovorody. "Pravo", 25, 26-32. (in Ukrainian)

Dorohan-Pysarenko, L. O. (2014). Oplata pratsi derzhavnykh sluzhbovtsiv: orhanizatsiino-oblikovyi aspekt [Remuneration of public servants: Organizational-accounting aspect]. Visnyk Poltavskoi derzhavnoi ahrarnoi akademii, 3, 127-131. (in Ukrainian)

Vehera, V.M. (2015). Vstanovlennia rozmiru minimalnoi zarobitnoi platy yak sposib derzhavnoho rehulyuvannia oplaty pratsi v Ukraini [Establishing the rate of the minimum wage as a method of state regulation of wages in Ukraine]. Kharkiv: Pravo. (in Ukrainian)

Kapinus, M. R. (2005). Shliakhy vdoskonalennia systemy oplaty pratsi derzhavnykh sluzhbovtsiv u suchasnykh umovakh Ukrainy [Ways of improvement of the system of remuneration of public servants in the modern conditions of Ukraine]. Derzhavne upravlinnia: teoriia ta praktyka, 2, 34-39. (in Ukrainian)

Sokolova, O. A. (2016). Shchodo suttievykh oznak pravovoi katehorii "oplata pratsi derzhavnykh sluzhbovtsiv" [On essential features of the legal category "remuneration of public servants"]. Visnyk Natsionalnoi akademii pravovykh nauk Ukrainy, 4, 161-170. (in Ukrainian)

Kodeks zakoniv pro pratsiu Ukrainy [The Code of Labor Laws of Ukraine]. Vidomosti Verkhovnoii Rady URSR. Appendix to no. 50. (December 17, 1971). (in Ukrainian)

Pro oplatu pratsi [On remuneration]. Vidomosti Verkhovnoi Rady Ukrainy, 17, 121. (in Ukrainian) 